\title{
Interaction between PPAR y and SORL1 gene with Late-Onset Alzheimer's disease in Chinese Han Population
}

\author{
Hui Zhang ${ }^{1, *}$, Wei Zheng ${ }^{2, *}$, Linlin Hua ${ }^{2}$, Yutong Wang ${ }^{3}$, Jinfeng Li', Hongying Bai ${ }^{4}$, \\ Shanshan Wang ${ }^{1}$, Mingyao Du ${ }^{1}$, Xuelian Ma ${ }^{1}$, Chunyang $\mathrm{Xu}^{4}$, Xiaodong $\mathrm{Li}^{4}$, Bin \\ Gong $^{1}$ and Yunliang Wang ${ }^{4,1}$ \\ ${ }^{1}$ Department of Neurology, The 148 Central Hospital of PLA, Shandong, China \\ 2 The Second Affiliated Hospital of Zhengzhou University, Zhengzhou, China \\ 3 Medical College of Henan University, Kaifeng, China \\ ${ }^{4}$ Department of Neurology, The Second Affiliated Hospital of Zhengzhou University, Zhengzhou, China \\ * These authors have contributed equally to this work \\ Correspondence to: Yunliang Wang, email: wangylyl56@163.com
}

Bin Gong, email: gongbinbin23@sina.com

Keywords: SORL1; PPAR G; single nucleotide polymorphism; alcohol drinking; interaction

Received: January 10, $2017 \quad$ Accepted: February 12, $2017 \quad$ Published: February 25, 2017

Copyright: Zhang et al. This is an open-access article distributed under the terms of the Creative Commons Attribution License 3.0 (CC BY 3.0), which permits unrestricted use, distribution, and reproduction in any medium, provided the original author and source are credited.

\section{ABSTRACT}

Aims: To investigate the impact of sortilin-related receptor 1 gene 1 (SORL1) and peroxisome proliferator activated receptor gamma (PPAR G) gene single nucleotide polymorphisms (SNPs), gene- gene and gene- environment interactions and haplotype on late-onset Alzheimer's disease (LOAD) risk.

Methods: Hardy-Weinberg equilibrium (HWE), haplotype analysis and pairwise linkage disequilibrium (LD) analysis were investigated by using SNPStats (available online at http://bioinfo.iconcologia.net/SNPstats). Logistic regression was performed to investigate association between SNPs and LOAD. Generalized multifactor dimensionality reduction (GMDR) was used to investigate the interaction among genegene and gene- environment interaction.

Results: Logistic regression analysis showed that LOAD risk was significantly higher in carriers of the A allele of rs1784933 polymorphism than those with GG (GA+ AA versus GG), adjusted OR $(95 \% \mathrm{CI})=1.63(1.27-1.98)$, and higher in carriers of $G$ allele of the rs1805192 polymorphism than those with CC (CG+ GG versus CC), adjusted OR $(95 \% C I)=1.70(1.25-2.27)$. GMDR analysis suggested a significant two-locus model $(p=0.0010)$ involving rs1784933 and rs1805192, and a significant two-locus model $(p=0.0100)$ involving rs1784933 and alcohol drinking. Haplotype containing the rs1784933- A and rs689021- $C$ alleles were associated with a statistically increased LOAD risk (OR $=1.86,95 \% \mathrm{CI}=1.37-2.52, p<0.001)$.

Conclusions: We conclude that rs1784933 and rs1805192 minor alleles, genegene interaction between rs1784933 and rs1805192, gene- environment interaction between rs1784933 and alcohol drinking, and haplotype containing the rs1784933- A and rs689021- C alleles are all associated with increased LOAD risk.

\section{INTRODUCTION}

Alzheimer's disease (AD) was the main cause for dementia in persons with middle and old age [1], and is a complex and progressive neurodegeneration characterised by large numbers of senile plaques and neurofibrillary tangles in the brain [2]. Clinically, late-onset $\mathrm{AD}$ (LOAD) is more common type of $\mathrm{AD}$ and the heritability for susceptibility to LOAD could be $80 \%$ in previous studies [3]. The etiology and pathogenesis of LOAD are still not clear, $\mathrm{AD}$ was a multifactorial disease and the complex pathology was resulted by the interaction of both genetics 
Table 1: Description and Probe sequence for 6 SNPs used for Taqman fluorescence probe analysis

\begin{tabular}{|l|l|l|c|l|}
\hline SNP ID & Chromosome & $\begin{array}{l}\text { Functional } \\
\text { Consequence }\end{array}$ & Major/ minor alleles & Nucleotide sequences/ Probe sequence \\
\hline SORL1 & & & & \\
\hline rs689021 & $11: 121500411$ & Intron variant & T/C & $\begin{array}{l}\text { Forward: ACGTTGGATGACCTTACAGATGATGCAGCC } \\
\text { Reverse: ACGTTGGATGGGCCATAGTTTCTAGCATC }\end{array}$ \\
\hline rs3824966 & $11: 121577474$ & Intron variant & G/C & $\begin{array}{l}\text { Forward: ACGTTGGATGCCAAGCTAATTCTCAGAGCC } \\
\text { Reverse: ACGTTGGATGTTGACAGCACTCATCCGTTC }\end{array}$ \\
\hline rs1784933 & $11: 121618707$ & Intron variant & G/A & $\begin{array}{l}\text { Forward: ACGTTGGATGTTTGAAGCAGTTCCAGGGTC } \\
\text { Reverse: ACGTTGGATGGAATGGAAGAGGACATCAGC }\end{array}$ \\
\hline PPARG & $3: 12421677$ & Intron variant & A/G & $\begin{array}{l}\text { 5'-AGATACGGGGGAGGAAATTCACTGG[A/G] } \\
\text { TTTTACAATATATTTTCAAGGCAA-3' }\end{array}$ \\
\hline rs709158 & $\begin{array}{l}\text { Intron variant, } \\
\text { upstream variant } \\
\text { 2KB }\end{array}$ & C/G & $\begin{array}{l}\text { 5'-TTGGCATTAGATGCTGTTTTGTCTT[C/G] } \\
\text { ATGGAAAATACAGCTATTCTAGGAT-3' }\end{array}$ \\
\hline rs10865710 & $3: 12311699$ & Missense & $\begin{array}{l}\text { 5'-ACCTCAGACAGATTGTCACGGAACA[C/T] } \\
\text { GTGCAGCTACTGCAGGTGATCAAGA-3' }\end{array}$ \\
\hline rs1805192 & $3: 12379739$ & & & \\
\hline
\end{tabular}

and environmental factors, however, until recently, the only reliable risk factor, the e4 allele of apolipoprotein $\mathrm{E}(A P O E)$ was verified. It was necessary to find and validate biomarkers for $\mathrm{AD}$ prevention, especially for LOAD, which has a strong genetic component [4], and several genes have been identified in the genome-wide association studies $[5,6]$, including the neuronal sortilinrelated receptor $(S O R L 1)$ [7] and peroxisome proliferator activated receptor gamma (PPAR G) gene [8].

SORL1 gene locates on chromosome 11q23.2-q24.2 [9]. Recent studies and replication studies have indicated that polymorphisms within SORL1 gene were associated with susceptibility to AD, which support the association between SNPs within SORL1 gene and AD risk [10- 13]. However, the other studies concluded controversial results, which indicated a weak or no association between SNPs in SORL1 gene and AD risk in Caucasian populations [14-16]. Recently, some studies reported that PPAR G can regulate amyloidogenic pathways $[17,18]$, they suggest that PPAR $G$ may be a potential candidate gene for AD. However, results on association between PPAR $G$ and LOAD were inconsistent yet $[19,20]$. In addition, LOAD susceptibility could be influenced by both environmental and genetic factors, and their synergistic effects between gene and environment, and previous studies have suggested that alcohol drinking was an important risk factor of $\operatorname{LOAD}[21,22]$. However, till now, less study focused on gene- alcohol drinking interaction on LOAD risk.

In consideration of the previous inconsistent results on association of PPAR G and SORL1 gene with LOAD, less numbers study on gene- alcohol drinking interaction and linkage disequilibrium (LD) among SNPs. In this study, we aimed to investigate the impact of PPAR G and SORL1 gene SNPs, additional gene- gene, gene- environment interaction and haplotype combination on LOAD risk.

\section{MATERIALS AND METHODS}

\section{Participants}

In this case-control study, participants were consecutively recruited between January 2009 and November 2014 from the Second Affiliated Hospital of Zhengzhou University. Clinical diagnosis of probable $\mathrm{AD}$ is made according to the revised criteria of National Institute of Neurological and Communicative Disorders and Stroke/ Alzheimer's Disease and Related Disorders Association (NINCDS/ ADRDA) [23], participants with advanced, severe, progressive, or unstable infectious, metabolic, immunologic, endocrinological, hepatic, hematological, pulmonary, cardiovascular, gastrointestinal, and/or urological diseases are excluded. The detailed participant selection methods have been described in our previous study [24]. Data on demographic information, mini-mental state examination (MMSE), educational year, lifestyle risk factors, smoking and drinking status, prevalence of stroke, prevalence of diabetes and family history of AD for all participants are obtained using a questionnaire administered by trained staffs. Body weight, height and waist circumference (WC) are measured, and body mass index (BMI) are calculated. Blood samples are collected in the morning after at least 8 hours of fasting. All plasma and serum samples are frozen at $-80^{\circ} \mathrm{C}$ until laboratory testing. Plasma glucose is measured using an oxidase enzymatic method. The concentrations of HDL cholesterol and triglycerides are assessed enzymatically 
Table 2: General characteristics of $\mathbf{8 8 0}$ study participants in case and control group

\begin{tabular}{|l|c|c|c|}
\hline Variables & $\begin{array}{l}\text { Case group } \\
(\boldsymbol{n}=\mathbf{4 3 0})\end{array}$ & $\begin{array}{l}\text { Normal group } \\
(\boldsymbol{n}=\mathbf{4 5 0})\end{array}$ & $\boldsymbol{p}$-values \\
\hline Age (year) & $81.4 \pm 16.1$ & $82.3 \pm 15.7$ & 0.401 \\
\hline Males, N (\%) & $246(57.2)$ & $268(59.6)$ & 0.480 \\
\hline Smoke, N (\%) & $151(35.1)$ & $145(32.2)$ & 0.364 \\
\hline Alcohol consumption, N (\%) & $188(43.7)$ & $160(35.6)$ & 0.013 \\
\hline WC $(\mathrm{cm})$ & $89.2 \pm 19.8$ & $87.7 \pm 19.4$ & 0.257 \\
\hline BMI $\left(\mathrm{kg} / \mathrm{m}^{2}\right)$ & $25.1 \pm 8.9$ & $24.8 \pm 9.1$ & 0.621 \\
\hline FPG $(\mathrm{mmol} / \mathrm{L})$ & $5.8 \pm 1.6$ & $5.5 \pm 1.9$ & 0.012 \\
\hline TG $(\mathrm{mmol} / \mathrm{L})$ & $1.4 \pm 0.8$ & $1.3 \pm 0.7$ & 0.048 \\
\hline TC $(\mathrm{mmol} / \mathrm{L})$ & $4.6 \pm 0.8$ & $4.5 \pm 0.9$ & 0.082 \\
\hline HDL $(\mathrm{mmol} / \mathrm{L})$ & $1.21 \pm 0.65$ & $1.34 \pm 0.63$ & 0.002 \\
\hline Stroke & $16(3.72)$ & $20(4.44)$ & 0.255 \\
\hline MMSE $(\mathrm{scores})$ & $15.16 \pm 5.51$ & $29.12 \pm 4.97$ & $<0.001$ \\
\hline Diabetes & $36(8.37)$ & $43(9.56)$ & 0.539 \\
\hline Educational year & $7.5 \pm 3.12$ & $7.8 \pm 3.31$ & 0.167 \\
\hline
\end{tabular}

Note: Means \pm standard deviation for age, WC, BMI, FPG, TC, TG, HDL-C and ANP; TC, total cholesterol; HDL, high density lipoprotein; FPG, fast plasma glucose; TG, triglyceride; WC, waist circumference; BMI, body mass index; MMSE, mini-mental state examination;

using an automatic biochemistry analyzer (Hitachi Inc., Tokyo, Japan) and commercial reagents.

\section{Genomic DNA extraction and genotyping}

SNPs within the SORL1 and PPAR $G$ gene were selected according to the following methods: 1) SNPs, which have been reported associations with AD and not been well studied; 2) SNPs, the MAF of which were more than $5 \%$. At last, three SNPs of SORL1 gene and three SNPs of PPAR $G$ gene are selected for genotyping in the study, including: rs709158, rs1805192 and rs10865710 within PPAR $G$ gene, rs1784933, rs3824966 and rs689021 within SORL1 gene. Genomic DNA is extracted from EDTA-treated whole blood, using the DNA Blood Mini Kit (Qiagen, Hilden, Germany) according to the manufacturer's instructions. The genotyping methods for PPAR $G$ gene have been described in our previous study [24]. Genotyping of three SNPs within SORL1 gene were performed using polymerase chain reaction and restriction fragment length polymorphism (PCR-RFLP) analysis. PCR primer sequences for each polymorphism were shown in Table 1 . The PCR reactions were carried out in a final volume of $25 \mu \mathrm{l}$ containing: $10 \times \mathrm{PCR}$ buffer, $4.5 \mathrm{mM} \mathrm{MgCl}_{2}$ (Roche, Germany), $0.4 \mathrm{mM}$ of each dNTP (Fermentas, Germany), 10 pmol of each primer, 30 ng template DNA, 1 U Taq DNA polymerase (Roche, Germany) and sterile distilled water up to $25 \mu \mathrm{l}$. PCR conditions were: $94{ }^{\circ} \mathrm{C}$ for $15 \mathrm{~min}$, then 45 cycles of $94{ }^{\circ} \mathrm{C}$ for $20 \mathrm{~s}, 56{ }^{\circ} \mathrm{C}$ for $30 \mathrm{~s}$, and $72{ }^{\circ} \mathrm{C}$ for $1 \mathrm{~min}$, with a final extension at $72{ }^{\circ} \mathrm{C}$ for $30 \mathrm{~min}$ and then reactions held at 4 ${ }^{\circ} \mathrm{C}$.

\section{Statistical analysis}

The means and standard deviations (SD) were calculated for normally distributed continuous variables, and percentages were calculated for categorical variables. The categorical data were analyzed using $\chi^{2}$ test. Further, continuous variables were analyzed using Student's t test. Hardy-Weinberg equilibrium (HWE), haplotype analysis and pairwise LD analysis were investigated by using SNPStats (available online at http://bioinfo. iconcologia.net/SNPstats). Logistic regression was performed to investigate association between SNPs and LOAD. Generalized multifactor dimensionality reduction (GMDR) was used to investigate the interaction among gene- gene and gene- environment interaction, crossvalidation consistency, the testing balanced accuracy, and the sign test, to assess each selected interaction were calculated. The cross-validation consistency score is a measure of the degree of consistency with which the selected interaction is identified as the best model among all possibilities considered. Testing-balanced accuracy is a measure of the degree to which the interaction accurately predicts case-control status, and yields a score between 0.50 (indicating that the model predicts no better than chance) and 1.00 (indicating perfect prediction). Finally, the sign test, or permutation test (providing empirical P-values), for prediction accuracy can be used to measure the significance of an identified model. 
Table 3: Genotype and allele frequencies of 6 SNPs between case and control group

\begin{tabular}{|c|c|c|c|c|c|c|}
\hline \multirow{2}{*}{ Gene/ SNP } & \multirow{2}{*}{$\begin{array}{l}\text { Genotypes and } \\
\text { Alleles }\end{array}$} & \multicolumn{2}{|c|}{ Frequencies $N(\%)$} & \multirow{2}{*}{ OR(95\%CI)* } & \multirow{2}{*}{$P$ - values } & \multirow{2}{*}{$\begin{array}{l}\text { HWE test for } \\
\text { controls }\end{array}$} \\
\hline & & Control $(n=450)$ & Case $(n=430)$ & & & \\
\hline \multicolumn{7}{|l|}{ SORL1 } \\
\hline \multirow[t]{8}{*}{ rs689021 } & Co-dominant & & & & & \\
\hline & TT & $271(60.2)$ & $235(54.6)$ & 1.00 & & 0.360 \\
\hline & $\mathrm{TC}$ & $152(33.8)$ & $153(35.6)$ & $1.13(0.82-1.85)$ & 0.621 & \\
\hline & $\mathrm{CC}$ & $27(6.0)$ & $42(9.8)$ & $1.40(0.89-1.98)$ & 0.506 & \\
\hline & Dominant & & & & & \\
\hline & TT & $271(60.2)$ & $235(54.6)$ & 1.00 & & \\
\hline & $\mathrm{TC}+\mathrm{CC}$ & $179(39.8)$ & $195(45.4)$ & $1.19(0.83-1.89)$ & 0.605 & \\
\hline & Allele, C (\%) & $206(22.9)$ & $237(27.6)$ & & & \\
\hline \multirow[t]{8}{*}{ rs3824966 } & Co-dominant & & & & & \\
\hline & GG & $276(61.3)$ & $243(56.5)$ & 1.00 & & 0.691 \\
\hline & GC & $151(33.6)$ & $156(36.3)$ & $1.27(0.95-1.71)$ & 0.236 & \\
\hline & $\mathrm{CC}$ & $23(5.1)$ & $31(7.2)$ & $1.45(0.81-2.22)$ & 0.379 & \\
\hline & Dominant & & & & & \\
\hline & GG & $276(61.3)$ & $243(56.5)$ & 1.00 & & \\
\hline & $\mathrm{GC}+\mathrm{CC}$ & $174(38.7)$ & $187(43.5)$ & $1.42(0.92-1.87)$ & 0.252 & \\
\hline & Allele, C (\%) & $197(21.9)$ & $218(25.3)$ & & & \\
\hline \multirow[t]{8}{*}{ rs 1784933} & Co-dominant & & & & & 0.999 \\
\hline & GG & $288(64.0)$ & $198(46.1)$ & 1.00 & & \\
\hline & GA & $144(32.0)$ & $182(42.3)$ & $1.55(1.24-1.91)$ & $<0.001$ & \\
\hline & AA & $18(4.0)$ & $50(11.6)$ & $2.08(1.41-2.92)$ & $<0.001$ & \\
\hline & Dominant & & & & & \\
\hline & GG & $288(64.0)$ & $198(46.1)$ & 1.00 & & \\
\hline & $\mathrm{GA}+\mathrm{AA}$ & $162(36.0)$ & $232(53.9)$ & $1.63(1.27-1.98)$ & $<0.001$ & \\
\hline & Allele, A (\%) & $180(20.0)$ & $282(32.8)$ & & & \\
\hline \multicolumn{7}{|l|}{ PPAR G } \\
\hline \multirow[t]{8}{*}{ rs1805192 } & Co-dominant & & & & & 0.073 \\
\hline & $\mathrm{CC}$ & $283(62.9)$ & $212(49.3)$ & 1.00 & & \\
\hline & $\mathrm{CG}$ & 139(30.9) & $164(38.1)$ & $1.57(1.21-1.79)$ & $<0.001$ & \\
\hline & GG & $28(6.2)$ & $54(12.6)$ & $2.15(1.42-2.98)$ & $<0.001$ & \\
\hline & Dominant & & & & & \\
\hline & $\mathrm{CC}$ & $283(62.9)$ & $212(49.3)$ & 1.00 & & \\
\hline & $\mathrm{CG}+\mathrm{GG}$ & $167(37.1)$ & $218(50.7)$ & $1.70(1.25-2.27)$ & $<0.001$ & \\
\hline & Allele, G (\%) & $195(21.7)$ & $272(31.7)$ & & & \\
\hline \multirow[t]{8}{*}{ rs 10865710} & Co-dominant & & & & & 0.226 \\
\hline & $\mathrm{CC}$ & $255(56.7)$ & $234(54.4)$ & 1.00 & & \\
\hline & $\mathrm{CG}$ & $161(35.8)$ & $160(37.2)$ & $1.07(0.86-1.48)$ & 0.628 & \\
\hline & GG & $34(7.6)$ & $36(8.4)$ & $1.02(0.70-1.69)$ & 0.746 & \\
\hline & Dominant & & & & & \\
\hline & $\mathrm{CC}$ & $255(56.7)$ & $234(54.4)$ & 1.00 & & \\
\hline & $\mathrm{CG}+\mathrm{GG}$ & $195(43.4)$ & $196(45.6)$ & $1.06(0.87-1.51)$ & 0.656 & \\
\hline & Allele, G (\%) & $229(25.4)$ & $232(27.0)$ & & & \\
\hline \multirow[t]{5}{*}{ rs709158 } & Co-dominant & & & & & \\
\hline & AA & $263(58.4)$ & $240(55.8)$ & 1.00 & & 0.836 \\
\hline & $\mathrm{AG}$ & $161(35.8)$ & $157(36.5)$ & $1.02(0.81-1.41)$ & 0.434 & \\
\hline & GG & $26(5.8)$ & $33(7.7)$ & $1.11(0.78-1.62)$ & 0.592 & \\
\hline & Dominant & & & & & \\
\hline
\end{tabular}




\begin{tabular}{|l|l|l|l|l|l|l|}
\hline & AA & $263(58.4)$ & $240(55.8)$ & 1.00 & & \\
\hline & AA+GG & $187(41.6)$ & $190(44.2)$ & $1.05(0.80-1.45)$ & 0.483 & \\
\hline & Allele, G (\%) & $213(23.7)$ & $223(25.9)$ & & & \\
\hline
\end{tabular}

*Adjusted for gender, age, smoking and alcohol status, BMI, WC, FPG, TC, TG, HDL, educational year, prevalence of stroke, prevalence of diabetes.

Table 4: Best gene-gene interaction models, as identified by GMDR

\begin{tabular}{|c|c|c|c|c|}
\hline Locus no. & Best combination & $\begin{array}{l}\text { Cross-validation } \\
\text { consistency }\end{array}$ & $\begin{array}{l}\text { Testing } \\
\text { accuracy }\end{array}$ & p-values* \\
\hline \multicolumn{5}{|c|}{ Gene- gene interaction } \\
\hline 2 & rs1784933 rs1805192 & $9 / 10$ & 0.6270 & 0.0010 \\
\hline 3 & rs1784933 rs1805192 rs10865710 & $8 / 10$ & 0.5399 & 0.0547 \\
\hline 4 & rs1784933 rs1805192 rs10865710 rs3824966 & $7 / 10$ & 0.5399 & 0.1719 \\
\hline 5 & rs1784933 rs1805192 rs10865710 rs3824966 rs689021 & $7 / 10$ & 0.4958 & 0.3770 \\
\hline 6 & rs1784933 rs1805192 rs10865710 rs3824966 rs689021 rs709158 & $6 / 10$ & 0.4958 & 0.4258 \\
\hline \multicolumn{5}{|c|}{ Gene- environment interaction } \\
\hline 21 & rs1784933 alcohol drinking & $10 / 10$ & 0.6072 & 0.0100 \\
\hline 3 & rs1784933 rs1805192 alcohol drinking & $8 / 10$ & 0.5399 & 0.1719 \\
\hline 4 & rs1784933 rs1805192 rs10865710 alcohol drinking & $7 / 10$ & 0.5399 & 0.1719 \\
\hline 5 & rs1784933 rs1805192 rs10865710 rs3824966 alcohol drinking & $6 / 10$ & 0.4958 & 0.4258 \\
\hline 6 & $\begin{array}{llll}\begin{array}{l}\text { rs1784933 rs1805192 rs10865710 rs3824966 rs689021 alcohol } \\
\text { drinking }\end{array} \\
\end{array}$ & $5 / 10$ & 0.4958 & 0.3770 \\
\hline 7 & $\begin{array}{l}\text { rs1784933 rs1805192 rs10865710 rs3824966 rs689021 rs709158 } \\
\text { alcohol drinking }\end{array}$ & $6 / 10$ & 0.4958 & 0.9893 \\
\hline
\end{tabular}

*Adjusted for gender, age, smoking and alcohol status, BMI, WC, FPG, TC, TG, HDL, educational year, prevalence of stroke, prevalence of diabetes.

\section{RESULTS}

A total of 880 participants (514 males, 366 females) were selected, including 430 LOAD patients and 450 control subjects. The mean age of all participants was 81.7 \pm 15.9 years old. Table 2 shows the general characteristics, clinical and blood biochemical index for all participants. The cases have the higher alcohol- drinking rate than controls. The means of FPG and TG were significantly higher in cases and controls, but the mean of HDL was lower in cases and controls.

In Table 3, the frequencies for the rs1784933- A allele within SORL1 gene and rs1805192- G allele within PPAR $G$ were significantly higher in LOAD cases than that in controls. The carriers with the rs1784933-A allele have higher LOAD risk than those with GG genotype (GA+ AA versus GG), adjusted OR $(95 \% \mathrm{CI})=1.63(1.27-1.98)$, and the carriers with rs1805192- $\mathrm{G}$ allele also have higher LOAD risk than those with $\mathrm{CC}$ genotype $(\mathrm{CG}+\mathrm{GG}$ versus $\mathrm{CC})$, adjusted OR $(95 \% \mathrm{CI})=1.70(1.25-2.27)$. However, we the others SNP within SORL1 and PPAR G gene were not associated with LOAD susceptibility after covariates adjustment.
GMDR analysis was used to investigate the impact of the interaction among 6 SNPs within SORL1 and PPAR $G$ gene on LOAD risk. Table 4 shows a significant two-locus model $(\mathrm{p}=0.0010)$ involving rs1784933 and rs1805192, and in this model, the cross- validation consistency was 9/ 10, and the testing accuracy was $62.70 \%$. We also found a significant two-locus model ( $\mathrm{p}$ $=0.0100$ ) involving rs1784933 and alcohol drinking, and in this model, the cross-validation consistency was 10 / 10 , and the testing accuracy was $60.72 \%$, after covariates adjustment for alcohol consumption status, FPG, TG and HDL (Table 5).

Pairwise LD analysis between SNPs was performed and D' values were shown in Table 5, we found that just $\mathrm{D}^{\prime}$ value between rs1784933 and rs689021 within SORL1 gene was 0.823 , which shown a strong chain reaction. So we also conducted haplotype analysis between the two SNPs. We found that the most common haplotype in SORL1 gene was rs1784933- G and rs689021- T haplotype, the frequency of which was 0.4701 and 0.5467 in case group and control group. Haplotype containing the rs1784933- A and rs689021- C alleles were associated with a statistically increased LOAD risk $(\mathrm{OR}=1.86$, $95 \% \mathrm{CI}=1.37-2.52, P<0.001)($ Table 6$)$. 
Table 5: The D' values among SNPs within PPAR G and SORL1 gene for the linkage disequilibrium test

\begin{tabular}{|l|c|c|}
\hline \multicolumn{1}{|c|}{ SNPs } & \multicolumn{2}{|c|}{ D'values } \\
\hline PPAR $G$ gene & rs10865710 & rs709158 \\
\hline rs1805192 & 0.362 & 0.623 \\
\hline rs10865710 & - & 0.482 \\
\hline SORL1 gene & rs3824966 & rs689021 \\
\hline rs1784933 & 0.548 & 0.823 \\
\hline rs3824966 & - & 0.617 \\
\hline
\end{tabular}

Table 6: Haplotype analysis on association between $S O R L 1$ gene and LOAD risk

\begin{tabular}{|c|c|c|c|c|c|c|}
\hline \multirow{2}{*}{ Haplotypes } & \multirow{2}{*}{ rs1784933 } & \multirow{2}{*}{ rs689021 } & \multicolumn{2}{|c|}{ Frequencies } & \multirow{2}{*}{ OR $(95 \% \mathrm{CI})$} & \multirow{2}{*}{ p-values: } \\
\hline & & & Case group & Control group & & \\
\hline H1 & $\mathrm{G}$ & $\mathrm{T}$ & 0.4701 & 0.5467 & 1.00 & -- \\
\hline $\mathrm{H} 2$ & $\mathrm{~A}$ & $\mathrm{~T}$ & 0.2167 & 0.2131 & $1.17(0.84-1.68)$ & 0.590 \\
\hline $\mathrm{H} 3$ & $\mathrm{G}$ & $\mathrm{C}$ & 0.2035 & 0.1921 & $1.28(0.92-1.75)$ & 0.612 \\
\hline $\mathrm{H} 4$ & $\mathrm{~A}$ & $\mathrm{C}$ & 0.1097 & 0.0481 & $1.86(1.37-2.52)$ & $<0.001$ \\
\hline
\end{tabular}

*Adjusted for gender, age, smoking and alcohol status, BMI, WC, FPG, TC, TG, HDL, educational year, prevalence of stroke, prevalence of diabetes.

\section{DISCUSSION}

In this study, we found that both the rs1784933- A allele and the rs1805192- G allele were associated with increased LOAD risk. However, we the others SNP within SORL1 and PPAR G gene were not associated with LOAD susceptibility after covariates adjustment. Some studies have focused on the association between PPAR G and AD risk, however the results on this association were inconsistent. Some studies concluded different results in Finnish [19], Japanese [25] and Asians and Caucasians population [20], these studies indicated that SNP and haplotype analyses for PPAR $G$ gene were not significant associated with AD risk, so they conclude that PPAR $G$ did not related with AD in the Finnish population. However, some studies also confirmed a significant association of SNPs within PPAR $G$ with AD $[17,18]$.

Although this was not the first association study focused on the SNP of SORL1 polymorphism and the risk of LOAD risk, however, they also did not concluded consistent results. In 2007, Rogaeva et al [26] firstly reported an association between SNP in SORL1 gene and AD incidence. From then on, several population- based studies were conducted for other populations. Minster et al [15] suggested no association with LOAD risk in their cohort. The data by Liu et al [27] also suggested the similar results on relationship between genetic variants in SORL1 and the risk of AD. Some studies also found positive results on this association, which were similar with results obtained in current study. Kölsch et al [28] found that SORL1 gene variants were associated with increased AD risk. Bettens et al [10] also indicated a significant association between common SNP within SORL1 gene and LOAD, providing further evidence of genetic variations in SORL1 affecting susceptibility of LOAD. In a Japanese population, Kimura et al [29] found that SORL1 was genetically associated with Alzheimer disease, and the similar results were also obtained from the others studies [30-32].

In this study, we found that LOAD risk was determined by both SORL1 and PPAR G gene, and synergistic reaction of both gene and environmental factors, so we also conducted analysis on impact of gene- gene and gene- environment interaction on LOAD risk. We found a significant gene- gene interaction involving rs1784933 and rs1805192, and a significant gene- environment interaction involving rs1784933 and alcohol drinking. Previously, several environmental risk factors have been reported, including alcohol drinking $[21,22]$, which was associated with LOAD in this study. Previously just one study focused on the impact of interaction between SORL1 rs2070045 polymorphism and ApoE genotype with the late-onset Alzheimer's disease, but they showed no interaction effect between $A p o E 4$ and any of the rs2070045 genotypes. In this study we also conducted the haplotype analysis for the rs1784933 and rs689021 within SORL1 gene, the D' value of which was more than $0.8(0.823)$, we found a haplotype containing the rs1784933- A and rs689021- C alleles were associated with a statistically increased LOAD risk.

The current study has some limitations, which should be considered. Firstly, limited number of SNPs in SORL1 and PPAR G gene was included in this study, and in the future, more SNPs should be included in analysis. Secondly, more environmental factors should be included in the gene- environment analysis, not only for alcohol drinking. Thirdly, the results of interaction analysis should be checked in different population, not only in Chinese Han. 
In conclusion, we found that rs1784933 and rs1805192 minor alleles were associated with increased LOAD risk. We also found a significant gene- gene interaction between rs1784933 and rs1805192, geneenvironment interaction between rs1784933 and alcohol drinking, and haplotype containing the rs1784933- A and rs689021-C alleles were all associated with increased LOAD risk.

\section{ACKNOWLEDGMENTS}

The writing of this paper was supported by the 148 central hospital of PLA and the Second Affiliated Hospital of Zhengzhou University. We thank all the partners and staffs who help us in the process of this study. Zhang Hui and Zheng Wei contributed equally to this work

\section{CONFLICT OF INTEREST}

There is no conflict of interest.

\section{REFERENCES}

1. Heneka MT, O’Banion MK. Inflammatory processes in Alzheimer's disease. J Neuroimmunol. 2007; 184:69-91.

2. Carrasquillo MM, Belbin O, Hunter TA, Ma L, Bisceglio GD, Zou F, Crook JE, Pankratz VS, Dickson DW, GraffRadford NR, Petersen RC, Morgan K, Younkin SG. Replication of CLU, CR1, and PICALM associations with Alzheimer disease. Arch Neurol. 2010; 67:961-4.

3. Gatz M, Reynolds CA, Fratiglioni L, Johansson B, Mortimer JA, Berg S, Fiske A, Pedersen NL. Role of genes and environments for explaining Alzheimer disease. Arch Gen Psychiatry. 2006; 63:168-74

4. Reitz C, Tosto G, Mayeux R, Luchsinger JA, NIA-LOAD/ NCRAD Family Study Group, Alzheimer's Disease Neuroimaging Initiative. Genetic Variants in the Fat and Obesity Associated (FTO) Gene and Risk of Alzheimer's Disease. PLoS ONE. 2012; 7: e50354.

5. Farrer LA, Cupples LA, Haines JL, Hyman B, Kukull WA, Mayeux R, Myers RH, Pericak-Vance MA, Risch N, van Duijn CM. Effects of age, gender and ethnicity on the association of apolipoprotein E genotype and Alzheimer disease. JAMA. 1997; 278: 1349-1356.

6. Sherva R, Farrer LA. Power and pitfalls of the genome wide association study approach to identify genes for Alzheimer disease. Cur Psychiatry Rep. 2011; 13: 138-146.

7. Feng X, Hou D, Deng Y, Li W, Tian M, Yu Z. SORL1 gene polymorphism association with late-onset Alzheimer's disease. Neurosci Lett. 2015; 584:382-9.

8. Hamilton G, Proitsi P, Jehu L, Morgan A, Williams J, O’Donovan MC, Owen MJ, Powell JF, Lovestone S. Candidate Gene Association Study of Insulin Signaling
Genes and Alzheimer's Disease: Evidence for SOS2, PCK1, and PPAR gamma as Susceptibility Loci. Am J Med Genet B Neuropsychiatr Genet. 2007; 144:508-16.

9. Andersen OM, Reiche J, Schmidt V, Gotthardt M, Spoelgen R, Behlke J, von Arnim CA, Breiderhoff T, Jansen P, Wu $\mathrm{X}$, Bales KR, Cappai R, Masters CL, et al. Neuronal sorting protein related receptor sorLA/LR11 regulates processing of the amyloidprecursor protein. Proc Natl Acad Sci U S A. 2005; 102:13461-6.

10. Bettens K, Brouwers N, Engelborghs S, De Deyn PP, Van Broeckhoven C, Sleegers K. SORL1 is genetically associated with increased risk for late-onset Alzheimer disease in the Belgian population. Hum Mutat. 2008; 29:769-70.

11. Lee JH, Cheng R, Honig LS, Vonsattel JP, Clark L, Mayeux R. Association between genetic variants in SORL1 and autopsy-confirmed Alzheimer disease. Neurology. 2008; 70:887-9.

12. Lee JH, Cheng R, Schupf N, Manly J, Lantigua R, Stern Y, Rogaeva E, Wakutani Y, Farrer L, St George-Hyslop $\mathrm{P}$, Mayeux R. The association between genetic variants in SORL1 and Alzheimer disease in an urban, multiethnic, community-based cohort. Arch Neurol. 2007; 64:501-6.

13. Lee JH, Chulikavit M, Pang D, Zigman WB, Silverman W, Schupf N. Association between genetic variants in sortilinrelated receptor 1 (SORL1) and Alzheimer's disease in adults with Down syndrome. Neurosci Lett 2007; 425: 105-109.

14. Cousin E, Macé S, Rocher C, Dib C, Muzard G, Hannequin D, Pradier L, Deleuze JF, Génin E, Brice A, Campion D. No replication of genetic association between candidate polymorphisms and Alzheimer's disease. Neurosci Lett. 2007; 425:105-9.

15. Minster RL, DeKosky ST, Kamboh MI. No association of SORL1 SNPs with Alzheimer's disease. Neurosci Lett. 2008; 440:190-2.

16. Li Y, Rowland C, Catanese J, Morris J, Lovestone S, O'Donovan MC, Goate A, Owen M, Williams J, Grupe A. SORL1 variants and risk of late-onset Alzheimer's disease. Neurobiol Dis. 2008; 29:293-6.

17. d'Abramo C, Massone S, Zingg JM, Pizzuti A, Marambaud P, Dalla Piccola B, Azzi A, Marinari UM, Pronzato MA, Ricciarelli R. Role of peroxisome proliferator-activated receptor gamma in amyloid precursor protein processing and amyloid beta-mediated cell death. Biochem J. 2005; 391:693-8.

18. Sastre M, Dewachter I, Rossner S, Bogdanovic N, Rosen E, Borghgraef P, Evert BO, Dumitrescu-Ozimek L, Thal DR, Landreth G, Walter J, Klockgether T, van Leuven F, et al. Nonsteroidal anti-inflammatory drugs repress beta-secretase gene promoter activity by the activation of PPAR gamma. Proc Natl Acad Sci U S A. 2006; 103:443-8.

19. Helisalmi S, Tarvainen T, Vepsäläinen S, Koivisto AM, Hiltunen M, Soininen H. Lack of genetic association 
between PPARG gene polymorphisms and Finnish lateonset Alzheimer's disease. Neurosci Lett. 2008; 441:233-6.

20. Wu Y, Wu Q, Zhang H, Chen C, Chen G, Yang H, Qin $\mathrm{D}, \mathrm{Fu} \mathrm{H}$. Lack of genetic associations between PPAR- $\gamma$ gene rs1801282 polymorphism and Alzheimer's disease in general population: A meta-analysis. Gene. 2015; 563:1204.

21. Heymann D, Stern Y, Cosentino S, Tatarina-Nulman O, Dorrejo JN, Gu Y. The Association Between Alcohol Use and the Progression of Alzheimer's Disease. Curr Alzheimer Res. 2016;13:1356-1362.

22. Huang WJ, Zhang X, Chen WW. Association between alcohol and Alzheimer's disease. Exp Ther Med. 2016; 12:1247-1250.

23. Dubois B, Feldman HH, Jacova C, Dekosky ST, BarbergerGateau P, Cummings J, Delacourte A, Galasko D, Gauthier S, Jicha G, Meguro K, O’brien J, Pasquier F, et al. Research criteria for the diagnosis of Alzheimer's disease: revising the NINCDS-ADRDA criteria. Lancet Neurol. 2007; 6:734-746.

24. Geng S, Wang Y, Sun Y, Li J, Yin H, Zeng Z, Yang X, Zhang Y, Wang Y. Gene- gene Interaction between CYP2J2 and PPAR - $\gamma$ gene on Late-Onset Alzheimer's disease in the eastern Chinese Han Population. Behav Brain Res. 2016. doi: 10.1016/j.bbr.2016.07.010

25. Shibata N, Motoi Y, Tomiyama H, Ohnuma T, Kuerban B, Tomson K, Komatsu M, Shimazaki H, Hattori N, Arai H. Lack of Genetic Associations of PPAR- $\gamma$ and PGC- $1 \alpha$ with Alzheimer's Disease and Parkinson's Disease with Dementia. Dement Geriatr Cogn Dis Extra. 2013; 3:161-7.

26. Rogaeva E, Meng Y, Lee JH, Gu Y, Kawarai T, Zou F, Katayama T, Baldwin CT, Cheng R, Hasegawa H, Chen F, Shibata N, Lunetta KL, et al. The neuronal sortilin-related receptor SORL1 is genetically associated with Alzheimer disease. Nat Genet. 2007; 39:168-77.
27. Liu F, Ikram MA, Janssens AC, Schuur M, de Koning I, Isaacs A, Struchalin M, Uitterlinden AG, den Dunnen JT, Sleegers K, Bettens K, Van Broeckhoven C, van Swieten $\mathrm{J}$, et al. A study of the SORL1 gene in Alzheimer's disease and cognitive function. J Alzheimers Dis. 2009; 18:51-64.

28. Kölsch H, Jessen F, Wiltfang J, Lewczuk P, Dichgans M, Teipel SJ, Kornhuber J, Frölich L, Heuser I, Peters $\mathrm{O}$, Wiese B. Association of SORL1 gene variants with Alzheimer's disease. Brain Res. 2009; 1264:1-6.

29. Kimura R, Yamamoto M, Morihara T, Akatsu H, Kudo T, Kamino K, Takeda M. SORL1 is genetically associated with Alzheimer disease in a Japanese population. Neurosci Lett. 2009; 461:177-80.

30. Miyashita A, Koike A, Jun G, Wang LS, Takahashi S, Matsubara E, Kawarabayashi T, Shoji M, Tomita N, Arai H, Asada T, Harigaya Y, Ikeda M, et al. SORL1 Is Genetically Associated with Late-Onset Alzheimer's Disease in Japanese, Koreans and Caucasians. PLoS One. 2013; 8:e58618.

31. Wen Y, Miyashita A, Kitamura N, Tsukie T, Saito Y, Hatsuta H, Murayama S, Kakita A, Takahashi H, Akatsu H, Yamamoto T, Kosaka K, Yamaguchi H, et al. SORL1 is Genetically Associated with Neuropathologically Characterized Late-Onset Alzheimer's Disease. J Alzheimers Dis. 2013; 35:387-94.

32. Olgiati P, Politis A, Albani D, Rodilossi S, Polito L, Ateri E, Zisaki A, Piperi C, Liappas I, Stamouli E, Mailis A, Atti AR, Ferrari B, et al. Association of SORL1 Alleles with Late-Onset Alzheimer's Disease. Findings from the GIGAS_LOAD Study and Mega-Analysis. Curr Alzheimer Res. 2012; 9:491-9. 